\title{
Day Times Microgram Per Milliliter Per Milligram Per Gram Per Day
}

National Cancer Institute

\section{Source}

National Cancer Institute. Day Times Microgram Per Milliliter Per Milligram Per Gram Per

Day. NCl Thesaurus. Code C117913.

Day times microgram per milliliter, divided by milligram per gram per day. 